\title{
LA FILOSOFÍA DEL
}

$\boldsymbol{n}$

LENGUAJE Y EL POEMA

ARGUMIENTATIVO EN

CUATRO POEMAS DE

EL OTRO, EL MISMO

(1964) DE JORGE LUIS

BORGES

sheridanmedina25@gmail.com Universidad Nacional Federico Villarreal

Fecha de recepción: agosto de 2019

Fecha de aceptación: diciembre de 2019

* Shéridan Medina Cabrera es licenciada en Literatura por la Universidad Nacional Federico Villarreal y magistra en Educación por la Universidad San Ignacio de Loyola. Cuenta con estudios concluidos de posgrado en Literatura con mención en Literatura Peruana y Latinoamericana por la Universidad Nacional Mayor de San Marcos. 
Resumen: Este trabajo analiza parte de la última etapa de la producción poética de Jorge Luis Borges, particularmente del libro El otro, el mismo (1964). Se propone que, en este poemario, Jorge Luis Borges presenta como problema fundamental la imposibilidad del lenguaje, en tanto tecnología comunicativa, para representar lo real o lo trascendente. Esta investigación se desarrolla principalmente en tres apartados. Después de la introducción, en el segundo apartado se desarrollan cuestiones previas al análisis de los poemas seleccionados. Aquí, se ubican precisiones del marco teórico, parte de la crítica en torno a la poesía de Jorge Luis Borges y, por último, una de las vertientes artísticas identificables en su obra. El tercer apartado está dedicado al análisis de los poemas "Composición escrita en un ejemplar de la Gesta de Beowulf” y "El mar”, a partir de la Retórica General Textual de Stefano Arduini y la Retórica argumentativa de Chaïn Perelman. Luego, en el cuarto apartado, se analizarán "Un poeta del siglo XIII” y “Una rosa y Milton”, empleando el modelo metafórico de Lakoff y Johnson.

Palabras clave: Poesía del lenguaje, Borges, retórica general textual, retórica argumentativa.

\title{
THE PHILOSOPHY OF LANGUAGE AND THE ARGUIENTATIVE POEM IN FOUR POEMS OF EL OTRO, EL MISMO (1964) BY JORGE LUIS BORGES
}

\begin{abstract}
This work analyzes part of the last stage of Jorge Luis Borges' poetic production, particularly of the book El otro, el mismo (1964). It is proposed that, in this collection of poems, Jorge Luis Borges presents as a fundamental problem the impossibility of language, as a communicative technology, to represent the real or the transcendent. This research is structured in three chapters. In the first, questions are developed prior to the analysis of the selected poems. Here, details of the theoretical framework are located, part of the criticism around the poetry of Jorge Luis Borges and, finally, one of the identifiable artistic aspects in his work. The second chapter is dedicated to the analysis of the poems "Composición escrita en un ejemplar de la Gesta de Beowulf" and "El mar", based on the textual General Rhetoric of Stefano Arduini and the argumentative Rhetoric of Chaïn Perelman. Finally, in the third chapter, "Un poeta del siglo XIII" and "Una rosa y Milton" will be analyzed, using the metaphorical model of Lakoff and Johnson.
\end{abstract}

Keywords: Poetry of Language, Borges, General Textual Rhetoric, Argumentative Rhetoric. 


\section{Introducción}

T a obra de Jorge Luis Borges alberga una multiplicidad de influencias artísticas y de Lensamiento; la convergencia de las experiencias y saberes occidentales y orientales en una conciencia que construye su identidad a partir de sus raíces latinoamericanas, redunda en una obra de una complejidad y riqueza portentosa. En este trabajo nos proponemos analizar parte de la última etapa del poeta. Se trata de El otro, el mismo (1964), proponemos que en este poemario Jorge Luis Borges presenta como problema fundamental la imposibilidad del lenguaje, como tecnología, para representar lo real o lo trascendente.

El presente artículo se estructura de la siguiente manera: En el primer apartado se desarrollan cuestiones previas al análisis de los poemas seleccionados. Aquí se ubican precisiones del marco teórico, parte de la crítica en torno a la poesía de Jorge Luis Borges y, por último, desarrollamos una de las vertientes artísticas que encontramos en su obra. El segundo apartado está dedicado al análisis de los textos a partir de nuestro marco teórico: la Retórica General Textual de Stefano Arduini y la Retórica argumentativa de Chaïn Perelman. Finalmente, en el tercer apartado se analizarán los poemas empleando el modelo metafórico de Lakoff y Johnson.

Para finalizar, debemos señalar que para este artículo estamos trabajando con la edición de la obra completa de Jorge Luis Borges de la editorial argentina Emecé de 1974.

\section{Aproximaciones al Campo Retórico de El otro, el mismo} (1964), de Jorge Iuis Borges

n la siguiente unidad, se desarrollará dos puntos fundamentales previos para la
comprensión y el análisis de los poemas de Jorge Luis Borges. En primer lugar, se propondrá un acercamiento a la categoría de campo retórico de Stefano Arduini, planteada en Prolegómemos a una teoría general de las figuras, seguidamente, comentaremos sobre dos de las principales vertientes artísticas en la obra de Jorge Luis Borges: el Ultraísmo y la propuesta filosófica de Arthur Schopenhauer. Finalmente, nos referiremos brevemente a la crítica en torno a la poesía de Borges.

\subsection{El campo retórico}

Esta categoría es la base desde la cual Stefano Arduini marca distancia con la Retórica restringida. El campo retórico se entiende como una 
(...) vasta área de los conocimientos y de las experiencias comunicativas adquiridas por el individuo, por la sociedad y por las culturas. Es el depósito de las funciones y de los medios comunicativos formales de una cultura $\mathrm{y}$, en cuanto tal, es el substrato necesario de toda comunicación. (Arduini, 2000, p. 47)

Es decir, el campo retórico no solo involucra los fenómenos estilísticos propios de la elocutio, sino que, además, integra el contexto escritural, el proceso de recepción del texto poético y las relaciones que se establecen entre este y las diferentes corrientes artísticas y filosóficas. El campo retórico es, entonces, el punto de interacción de los hechos retóricos, entendidos como los acontecimientos que conducen a la producción de un texto retórico y que incluyen todos los factores que hacen posible su realización (Arduini, 2000). Es el lugar de confluencia de múltiples variantes, factores y elementos, pero es, a la vez, el resultado de todos estos. En el caso de Jorge Luis Borges, no podríamos, por ejemplo, comprender su obra sin el conocimiento fundamental de corrientes poéticas como el Ultraísmo y el Expresionismo, por el lado artístico; y del pensamiento de Berkeley y Schopenhauer, por el lado filosófico. Además, en cuanto a referentes nacionales, la obra de Borges es inconcebible, según el propio autor, sin la influencia determinante de Macedonio Fernández.

La categoría de campo retórico planteada por Arduini se inserta en la denominada Retórica General Textual, que tiene entre sus representantes a Antonio García Berrio, Giovanni Bottiroli y Tomás Albaladejo. Todos ellos se caracterizan por presentar una "neorretórica", es decir, un modelo teórico que centre su atención en articular las figuras retóricas de estilo con el plano ideológico discursivo que subyace en el texto poético.

La importancia de considerar el campo retórico dentro de un análisis textual radica en la necesidad de insertar el texto poético en una red de significancia mayor. La interpretación que propone Arduini desde la Retórica General Textual, asume la definición de "cierta organización textual y las relaciones existentes entre ésta y los productores, la estructura del conjunto referencial y el contexto, en relación con el Campo Retórico en el cual nosotros actuamos comunicativamente" (Arduini, 2000, p. 50). En ese sentido, la propuesta de Arduini nos plantea un análisis retórico - hermenéutico de orientación interdisciplinaria, pues en él se insertan la Pragmática, la Sociolingüística, la Semiótica, la Teoría de la Recepción, entre otras. 


\subsection{Un breve balance de la crítica a la poesía de Jorge Luis Borges}

La obra de Jorge Luis Borges, extensa, compleja y diversa, se inaugura en la poesía, se abre paso en la ensayística, y logra su mayor reconocimiento con la cuentísitica, cúspide de su propuesta estética. Su naturaleza heterogénea; sin embargo, no es reflejo de una poética disgregada, azarosa, o insustancial, por el contrario, cada escrito es una expresión de las múltiples búsquedas constantes del autor a partir de una visión de mundo constituida desde sus jóvenes inicios por las influencias culturales, filosóficas, artísticas, tanto de la tradición occidental como la oriental. El género solo es parte de la estrategia discursiva que escoge el autor para abordar desde su particular visión de mundo, los tópicos, símbolos, personajes, que le permitirán exponer su propuesta. Las múltiples referencias de la cultura y filosofía, sobre todo occidental, el diálogo constante con la tradición literaria inglesa, irlandesa particularmente, han llevado a muchos lectores, y críticos también, a señalar que la obra de Borges no es una literatura propiamente latinoamericana, pues no establece vínculos con la realidad de su continente, tampoco reflexiona o critica su historia, su procesos y conflictos sociales. La obra de Borges parece, más bien, desterritorializarse del continente latinoamericano en aras de una propuesta universalista.

\subsubsection{La propuesta de Beatriz Sarlo}

Lo argentino y latinoamericano en la obra de Borges ha sido un tema frecuente en la crítica literaria que se ocupa del escritor argentino. Beatriz Sarlo en Borges, un escritor en las orillas (2007), se encarga de reflexionar en torno a la argentinidad de Borges; los diálogos entre lo nacional y cosmopolita, la influencia de las tradiciones gauchesca e inglesa, la posición del autor como parte de una nación periférica pero moderna. Desde la recepción europea, Borges resulta siendo un autor, incluso más universal que la propia literatura argentina. Sus constantes alusiones, vínculos y referencias textuales a los discursos y tradición occidental, terminan configurándolo como una voz sin nación o, en todo caso, sin nación latinoamericana. Como señala Sarlo, a partir de las lecturas europeas del autor,

Se obtiene un Borges que se explica en la cultura occidental y las versiones que esta cultura tiene de Oriente, prescindiendo de un Borges que también se explica en la cultura argentina y, especialmente, en la formación rioplatense. La reputación de Borges en el mundo lo ha purgado de nacionalidad. (2007, p. 8) 
De este modo, se ha leído al autor argentino, incluso en su propia patria, desde el lente europeo, el cual lo encasilla en los parámetros universalistas. Por otro lado, Sarlo reconoce que esta posición reafirma el amplio espectro discursivo del autor, al no ser leído desde una nacionalidad adquiere los matices, alcances y el posicionamiento privilegiado que solo un clásico universal detenta.

El lugar de enunciación de Borges determina el posicionamiento de su discurso y la propuesta estética, ambas señaladas por la crítica como "universales", y que, sin embargo, solo reafirman, para Sarlo, el carácter argentino y periférico de su obra. Para Borges, escribir desde Argentina no significó una manera de "evadir" su realidad latinoamericana, todo lo contrario, "la argentinidad", lo nacional, lo latinoamericano, son aspectos que forman parte crucial de su reflexión como intelectual y escritor. Asimismo, enfrentarse a una nación, por demás compleja por su historia, cultura, ubicación geográfica, como lo es la Argentina, significó siempre para Borges un reto; comprender la Argentina, era, en cierta medida, comprender su propia identidad. Según Sarlo:

No existe escritor más argentino que Borges: él se interrogó, como nadie, sobre la forma de la literatura en una de las orillas de occidente. En Borges, el tono nacional no depende de la representación de las cosas sino de la presentación de una pregunta: ¡cómo puede escribirse literatura en una nación culturalmente periférica? La obra de Borges nunca deja de rodear este problema que pertenece al núcleo de las grandes cuestiones abiertas en una nación joven, sin fuertes tradiciones culturales propias, colocada en el extremo sur de los dominios de España en américa, tierras finales que fueron la sede del virreinato menos rico, que tampoco pudo exhibir, como otras naciones latinoamericanas, grandes formaciones indígenas precolombinas. (2007, p. 11)

Escribir desde una nación periférica es escribir también desde los bordes de múltiples tradiciones; sin ser europeo Borges conoce y domina las culturas y lenguas inglesa, francesa, alemana, entre otras; siendo argentino, Borges entabla diálogo con la tradición oriental, pero también con la historia de la Argentina, con el arrabal, el tango, las costumbres rioplatenses. La obra de Borges no se ubica del todo en ningún territorio, cultural o físico; desde su primer estilo vanguardista, pasando por el cuento policial, los relatos fantásticos, la 
erudición de su ensayística, entre otros, el autor argentino parece transitar permaneciendo solo lo necesario en cada género, estilo, tema, cultura, lengua, territorio. Se trata de una obra que se construye desde los límites y tiende a la mezcla de las tradiciones que el autor siente más próximas, lo que define su carácter heterogéneo. En palabras de Sarlo:

A pesar de la perfecta felicidad del estilo, la obra de Borges tiene en el centro una grieta: se desplaza por el filo de varias culturas, que se tocan (o se repelen) en sus bordes. Borges desestabiliza las grandes tradiciones occidentales y las que conoció en Oriente, cruzándolas (en el sentido en que se cruzan los caminos, pero también en el sentido en que se mezclan las razas) en el espacio rioplatense. (2007, pp. 12-13)

Esta mezcla, en la cual radica la heterogeneidad de su obra, ha sido reconocida como la fuente de su tan característico cosmopolitismo, el cual se presenta como una suerte de estrategia, pues a partir de ella Borges propone una literatura argentina que dialoga y reordena las tradiciones culturales nacionales pero, además, la habilita para cortar, elegir y recorrer las literaturas extranjeras desde la periferia (Sarlo, 2007). Por otro lado, la relación que establece Borges con las literaturas occidentales extranjeras no es planteada desde términos de dependencia, sino, más bien, de igualdad; desde la marginalidad o periferia, el autor articula una literatura argentina propia y, dentro de su heterogeneidad y cosmopolitismo, original.

\subsubsection{La propuesta de Mario Goloboff}

Mario Goloboff, dedica un extenso y exhaustivo estudio a la obra del escritor argentino en Leer Borges (2014), el volumen consta de seis capítulos, en cada uno se desarrolla un aspecto en particular de la vastísima obra de Borges. En el apartado destinado a la obra poética, Goloboff inicia definiendo a la poesía del autor como una "entera búsqueda de la palabra poética" (p. 30). Esta propuesta atraviesa la frontera de la poesía y se inserta en el núcleo mismo de la ensayística y narrativa borgiana; toda reflexión en Borges está determinada por la misma preocupación: "replantear las condiciones del que escribe y las del proceso de creación, sus dificultades, sus fuentes, su sentido" (p. 30). Asimismo, el autor indaga en los confines del lenguaje en búsqueda del reencuentro con la "palabra mágica", 
aquella que sea "palabra-música (...) que, simultáneamente, sea fondo y forma" (p. 30). Precisamente, en el prólogo del poemario en estudio El otro, el mismo (1964), se presenta la imperiosa necesidad de volver a aquella magia: "La raíz del lenguaje es irracional y de carácter mágico (...) La poesía quiere volver a esa antigua magia” (p. 858), y esa será una de las consignas centrales del libro en mención.

Goloboff insiste en que la reflexión en torno al lenguaje en la poesía de Borges es la fuente del origen de toda la actividad poética y artística del autor, colocándose en el centro mismo de todas sus exploraciones, además, señala, "ha sido la persecución del verbo, y del verbo poético, la que simultáneamente expresa y produce otras búsquedas” (2014, p. 30). En ese sentido, la palabra se articula como eje desde el cual el poeta construye una estética propia a la que adhiere una diversidad de discursos, tradiciones y temáticas. En la poesía borgeana, desentrañar los misterios, alcances y límites de la herramienta lingüística es una práctica que motiva el proceso creador, a la vez que es su objetivo.

La insolvencia del carácter representativo del lenguaje, lo motiva a emprender nuevas exploraciones con la palabra; si el lenguaje de por sí es imperfecto, ¿cómo hallar la formula lingüística que pueda comunicar una verdad? De ahí el hermetismo del que a veces se acusa a la poesía de Borges; las figuras y artilugios lingüísticos son parte de la estrategia para acercarse a un referente esquivo. La dificultad de captar la esencia de la realidad, sean ciudades, personajes, sentimientos, motiva la exploración profunda de los registros lingüísticos empleados, pero a la vez, consiente de la imposibilidad y, hasta cierto punto, la inutilidad de este ejercicio, termina trasladandola al centro mismo de su poética, dando paso a la metapoesía. Un ejemplo es el uso de símbolos como la rosa para representar la inconsistencia del lenguaje como conflicto, así lo indica Goloboff:

El motivo de la rosa, por otra parte, perdurará como símbolo borgiano de las posibilidades e imposibilidades poéticas a lo largo de toda su obra; no solo ha seguido escribiendo con marcada insistencia poemas sobre las rosas, o acerca de ellas, o mencionándolas para marcar la distancia entre palabra poética y realidad a captar, sino que también ha dado como título, a un libro de versos (...). (2014, p. 35) 
Esta reflexión es desarrollada en "Una rosa amarilla", texto que forma parte de $E l$ Hacedor (1960), en el cual se afirma sobre Marino, personaje del relato, lo siguiente: "vio la rosa, como Adán pudo verla en el Paraíso, y sintió que ella estaba en su eternidad y no en sus palabras" (p. 795). El lenguaje, la palabra, termina siendo un arquetipo universal que no solo es parte de una preocupación estética por parte del autor, sino, según Borges, es un cuestionamiento que se remonta a los orígenes de la humanidad y su insuficiencia como herramienta expresiva ha determinado, y además explica, las construcciones que se han hecho del mundo a lo largo de la historia. La rosa es aquella esfera a la que el hombre no puede acceder por medio del lenguaje pero, a través de otros canales, puede ser percibida como parte de suya, en una simultaneidad cósmica.

El origen del lenguaje como preocupación central de la poética borgiana, que es enigma y problema según Goloboff, guarda estrecha relación con la concepción filosófica y visión de mundo que maneja el autor. Existe una certeza en Borges al concebir al lenguaje como interpretación, ordenación y construcción del mundo y el universo, certeza que lo convence a su vez de que la comprensión de estos solo será posible a través de la exploración de la palabra. Esta concepción se explica, en gran medida, por la teoría (o teorías) cabalística con las que Borges sentía gran afinidad

(...) cuyo axioma es que el universo ha sido creado por la palabra de Dios, el lenguaje es el punto de partida del mundo, el código con el que vamos a entenderlo, y el material con que el cosmos nos irá entregando sus nuevos secretos (...). (p. 45)

De ahí que la visión del mundo del autor le otorgue preponderancia a la palabra y la inscriba en el centro de su poética: es el único instrumento para acceder a la realidad aunque no la pueda aprehender por completo.

\subsection{Vertientes artísticas y filosóficas en la obra de Jorge Luis Borges}

Las vertientes artísticas y filosóficas que atraviesan la obra de Jorge Luis Borges son tan diversas y complejas, que reconocer y explicar el grado de influencia de cada una en la obra del argentino, sería una labor interminable. Por ello, solo nos enfocaremos en dos de estas vertientes: el Ultraísmo y la filosofía de Arthur Schopenhauer, principalmente la 
propuesta de El mundo como voluntad y representación (1819), al ser ambas determinantes en la poética que el autor argentino desarrolla en El otro, el mismo (1964), poemario que es motivo del presente estudio.

\subsubsection{El ultraísmo y las primeras aproximaciones a la palabra poética}

Antes de encontrar el camino ultraísta y fundar el movimiento vanguardista en Espańa, las primeras exploraciones del autor con la palabra poética se remontan a algunos ańos previos: a su juventud de lecturas y traducciones expresionistas. Es por ello que, antes de abordar la etapa Ultraísta del autor, habría que señalar el Expresionismo como un antecedente importante en su poética madura.

El primer contacto de Jorge Luis Borges con el Expresionismo fue durante su estadía en Suiza, entre 1914 y 1919. Durante aquellos años Borges se sumerge en la literatura alemana expresionista, particularmente en la poesía, y se interesa en poetas como Kurt Heynicke, Wilhelm Klemm, Ernst Stadler y August Strammde. Este periodo determinará la producción posterior del autor; entre 1920 y 1921 publica una serie de traducciones, tal es el caso de "Lírica expresionista. Síntesis", texto en el cual, tras una breve introducción, traduce a Wilhelm y Klemm (García, 2004).

El expresionismo como influencia en la poética de Borges, corresponde a un periodo previo e incipiente de la obra monumental del autor, vinculado a la labor de traducción que ejerció en sus primeros años de juventud. Se trata, pues, de la exploración de una vertiente que le sirvió para construir una identidad literaria, la cual no se afianzó hasta su involucramiento con el Movimiento ultraísta en 1920.

En 1920, inicia oficialmente la etapa ultraísta de Jorge Luis Borges. El autor publica en la revista Grecia de Sevilla un breve texto titulado "Al margen de la moderna lírica” dedicado a Isaac del Vando Villar, poeta ultraísta español de la llamada Generación del 27, en el cual expone, en primer lugar, el deslinde necesario de la propuesta ultraísta de la tradición lirica moderna; y en segundo, la reafirmación del movimiento ultraísta como "expresión recién redimida del transformismo en literatura" (Verani, 1986), el cual privilegia la metáfora como figura expresiva elemental. Esta urgencia de renovación y revolución de la estética moderna imperante aún a inicios de siglo XX en Europa, responde a una coyuntura artística, política, social, filosófica, determinada; nos encontramos ante el periodo vanguardista europeo, el ultraísmo se aúna a una serie de propuestas artísticas 
de igual corte innovador y contestatario, la tradición moderna se encuentra en una crisis definitiva.

Jorge Luis Borges define el Ultraísmo a lo largo de una serie de manifiestos, en "Al margen de la poesía”, señalará que

El ultraísmo no es quizás otra cosa que la espléndida síntesis de la literatura antigua, que la última piedra redondeando su milenaria fábrica. Esa premisa tan fecunda que considera las palabras no como puentes para las ideas, sino como fines en sí, halla en él su apoteosis. (Verani, 1986, p. 272)

En esta primera definición habría que rescatar como fundamental el protagonismo que se le otorga a la palabra, desligándola de su papel como mediadora de las ideas y focalizando su valor en sí misma. Luego, en el "Manifiesto del Ultra” de 1921, firmado por Jacobo Sureda, Fortunio Bonanova, Juan Alomar y Jorge Luis Borges, la propuesta estética ultraísta adquirirá una forma más definida:

Esta es la estética del Ultra. Su volición es crear: es imponer facetas insospechadas al universo. Pide a cada poeta una visión desnuda de las cosas, limpia de estigmas ancestrales; una visión fragante, como si ante sus ojos fuese surgiendo auroralmente el mundo. (Verani, 1986, p. 273)

El impulso renovador, que enfatiza en la originalidad de la palabra tendrá como objetivo "La creación por la creación" en la práctica poética. Este es el distintivo que marca la primera faceta poética de Borges; la propuesta ultraísta centra su estética en la forma, y dentro de ella, particularmente, en la metáfora como artilugio legítimo. Tiempo después, en Prisma: Revista Mural (diciembre 1921), los ultraístas proclaman: "Hemos sintetizado la poesía en su elemento primordial: la metáfora, a la que concedemos una máxima independencia, más allá de los jueguitos de aquellos que comparan entre sí cosas de forma semejante, equiparando con un circo a la luna” (Verani, 1986, pp. 284-285). La primera etapa de la producción poética de Borges estará signada bajo la influencia ultraísta de la metáfora; sin embargo, no pasará mucho tiempo para que el autor se distancie de este 
movimiento e, incluso, llegue a considerar a la metáfora como un elemento no sustancial en su poética.

Si bien en 1922 funda junto con otros artistas la revista ultraísta Proa, ya desde su retorno a Buenos Aires en el verano de 1921, Borges había iniciado su distanciamiento del movimiento. Cuando publica Fervor de Buenos Aires en 1923, los últimos estragos del ultraísmo se encontraban en descenso. Si retomamos los últimos manifiestos, en el titulado "Ultraísmo", publicado en la revista Nosotros, en diciembre de 1921, Borges lo esquematiza en cuatro principios:

- Reducción de la lírica a su elemento primordial: la metáfora.

- Tachadura de las frases medianeras, los nexos y los adjetivos inútiles.

- Abolición de los trebejos ornamentales, el confesionalismo, la circunstanciación, las prédicas y la nebulosidad rebuscada.

- Síntesis de dos o más imágenes en una, que ensancha de ese modo su facultad de sugerencias.

Estos principios, si bien se pueden distinguir aún en algunos poemas de Fervor de Buenos Aires (1923), terminan siendo segregados de la propuesta borgeana a partir de este poemario. Según Jaime Alazraki, en "Los dos estilos del primer Borges":

Borges no tardó mucho en renegar de la "equivocada secta ultraísta", o como resume Guillermo de Torre en su artículo de 1964 "Para la prehistoria ultraísta de Borges": "Su entusiasmo de una época, de unos años - de 1919 a 1922- pronto se trocó en desdén y aun en agresividad (...)” (p. 81). "La causa determinante de tal cambio" (en su poesía) habría sido, para De Torre, "el choque psíquico recibido por el reencuentro con su ciudad nativa, Buenos Aires, tras varios años de permanencia en Europa" (Alazraki, 1999, p. 82).

Efectivamente, uno de los temas que moviliza el poemario es el encuentro y desencuentro del poeta con la ciudad, Buenos Aires. Sin embargo, explorar la ciudad no solo se enmarca dentro las rutas espaciales previstas; se extiende, más bien, a exploraciones discursivas dentro de las cuales el cuestionamiento de la identidad argentina será, por 
ejemplo, fundamental. El distanciamiento de Borges de la estética ultraísta, visible a partir de Fervor en Buenos Aires, en la cual la poesía se articulaba a partir de la metáfora, no significará de ningún manera que el autor descarte su uso; a lo largo de su producción posterior, la metáfora será un recurso estilístico y de pensamiento distinguible dentro de su poética; sin embargo, no es capital para entender la propuesta lingüística y estética del autor, como veremos en los apartados posteriores de este artículo.

Finalmente, solo con el antecedente ultraísta en su poética, podría entenderse y explicarse la propuesta borgiana que se presenta ya cuajada en El otro, el mismo (1964), poemario que ocupa nuestra investigación. La exploración en torno a la metáfora y sus límites representacionales o miméticos, significa la gesta de una poética mayor que construye sus búsquedas expresivas desde un movimiento vanguardista del que irá desprendiéndose paulatinamente a medida que encuentra su propia voz. Carlos Alberto Villegas Uribe, señala lo siguiente acerca de este punto:

No importa que después abjurara de este movimiento y molestara a Guillermo de Torre; su narrativa vital y su voluntad de escritor ya estaba tocada por el imperativo de la perfección en el ritmo y las imágenes; en la búsqueda de la palabra precisa para describir los hechos y suscitar resonancias trascendentes y arquetípicas: aquellas huellas acústicas que conectan con la historia filogenética de la humanidad. (2008)

Es precisamente esa búsqueda de la palabra precisa y la afinidad con los arquetipos universales, los cuales marcarán su segunda etapa poética, cuyo inicio podríamos identificar en 1960 con El hacedor. El problema del lenguaje, o el verbo poético, su naturaleza y limitaciones para aprehender la realidad, será un cuestionamiento constante a lo largo de la poesía borgiana, particularmente en El otro, el mismo (1964), en el cual se evidencia, además, que en la incesante persecución de la palabra, se articulan otras búsquedas que se explican a partir de un sistema de pensamiento homogéneo, desde el cual se construye toda la obra del escritor argentino. Para la comprensión del sistema de pensamiento y, por ende, la poética de Jorge Luis Borges, la revisión de la propuesta filosófica de Arthur Schopenhauer, será primordial. 


\subsubsection{Arthur Schopenhauer, El mundo como voluntad y representación y la poética borgiana}

El cuestionamiento al lenguaje y su capacidad expresiva, no es solo un tópico temático en la poesía de Jorge Luis Borges; interpelar la propia herramienta artística, en este caso la palabra, es parte de la reflexión y la búsqueda personal que un poeta emprende para construir una identidad propia; pero en Borges, la cuestión del lenguaje trasciende una búsqueda de estilo en particular. Se trata, más bien, de una consecuencia de la concepción del mundo que el autor poseía, la cual condiciona su percepción y representación de la realidad inmediata. Borges entiende la escritura como una copia de un modelo determinado por la percepción del hombre, de manera que aprehender lo real está fuera de las capacidades del lenguaje y del propio hombre. Tanto lo real como el propio yo es inexistente para Borges, ambas son presencias cuya cognocibilidad es imposible, Borges sustenta esta visión de mundo amparado por las propuestas idealistas y fenomenológicas de la tradición europea, además de la gran influencia del pensamiento de Macedonio Fernández, con quien su padre tenía estrecha amistad y a quien en innumerables ocasiones reiteró admiración por su obra.

María del Carmen Rodriguez sostiene que, peculiarmente, Borges tomaba las “tesis idealistas que sostienen que el mundo es sueño o representación, hecho que implica la irrealidad del sujeto y objeto" (2009, p. 15). A partir de este principio fundamental, se puede explicar y entender la nulidad del individuo (o sujeto) en la obra de Borges y la apuesta por el arquetipo, el cual es universal y se traslada en diversos espacios y tiempos. Si el mundo es representación, no solo la filosofía puede explicarlo, sino, y sobre todo, la literatura, pues no solo se trata de una expresión cultural sino, además, de un paradigma de interpretación del mundo (Rodríguez, 2009) que permite cuestionar y explorar, desde el propio lenguaje, las diversas estructuras ideológicas, filosóficas, estéticas, de las que está hecho.

Una de las propuestas idealistas que Borges acunó a su visión de mundo y poética fue la de Arthur Schopenhauer, cuya obra conoció durante los años de su juventud en Suiza, principalmente las ideas vertidas en El mundo como voluntad y representación (1819), en la cual el filósofo alemán postula, básicamente, como tesis principal, “(...) la idealidad de un mundo recreado y limitado al solipsismo del individuo" (Rodríguez, 2009, p. 53). Dicha postura resulta de la simpatía del escritor argentino, pues asentaba los presupuestos de una poética que ya en sus orígenes cuestionaba la naturaleza de la realidad y reclamaba la creación de su propio universo. María del Carmen Rodríguez, señala que ya en 1944, 
Teodosio Fernández, había dado cuenta de la determinante influencia de Schopenhauer en la poética del argentino, según Fernández:

Schopenhauer no es solo un escritor atractivo, apto para la cita oportuna. Su pensamiento convenía sobremanera a alguien como Borges, consciente o inconscientemente empeñado en la búsqueda de caminos no realistas para la literatura, y favorablemente predispuesto hacia cualquier doctrina desrealizadora, apta para poner en entredicho las relaciones entre el lenguaje (la literatura) y la realidad, entre el universo y nuestras descripciones del mismo. (Rodríguez, 2009, p. 22)

En ese sentido, la base solipsista de este pensamiento, permitía el cuestionamiento de la realidad como fuente cognoscible de verdad absoluta, pues, si todo es una percepción del sujeto, el mundo se impondría como una multiplicidad de representaciones. Según Schopenhauer, el mundo como representación solo existiría a partir de la existencia de un sujeto que lo "perciba" como tal, es decir, el mundo no es mundo antes que un sujeto lo nomine y toda aquella caracterización de este es inexistente sin la mente de un sujeto que los perciba.

La influencia de Schopenhauer en la poética borgiana no es, sin embargo, aislada. Como mencionamos líneas arriba, el pensamiento de Schopenhauer se enmarca dentro de la corriente idealista de la cual Borges se nutrió durante los años que radicó en Suiza. En ese sentido, otro filósofo de la misma línea por el que sentía inclinación es el inglés George Berkeley, lo cual es previsible, puesto que Schopenhauer basa su pensamiento en el idealismo de Kant pero sobre todo en la propuesta filosófica de Berkeley. Es de esta escuela desde la cual Schopenhauer articulará la base de su pensamiento, y a partir del cual Borges construirá su visión de mundo, tal como lo explica Holloway:

Para Schopenhauer, el objeto, el mundo percibido (cuya substancia, claro, es sólo percepciones), es un mundo platónico de arquetipos tan eternos como el sujeto. La noción borgiana del mundo percibido es idéntica a la de Schopenhauer, excepto que Borges no habla específicamente de arquetipos platónicos sino más bien de unos momentos eternos o arquetípicos que finge 
descubrir en un temprano relato seudo-autobiográfico ("Sentirse en muerte", 1928). (1977, p. 628)

Esta visión de mundo articulada a partir de las propuestas filosóficas de la escuela idealista y en particular la de Schopenhauer, asentada en el convencimiento de que lo real es incognoscible y el mundo es solo representación solipsista, edifica una poética que se desarrolla incesantemente a lo largo de la obra del autor. Ensayos, cuentos, de diversa temática, explorarán en el núcleo de su trama la visión filosófica borgiana, los cuestionamientos metafísicos tan característicos de Borges, sobre todo en su poesía, no son otra cosa que expresiones, búsquedas, ejemplificaciones de una certeza mayor; el hombre está imposibilitado de acceder a lo real, la verdad absoluta, y solo, a partir de la literatura, tienta a percibir esa imposibilidad.

\section{Los Campos Figurativos y el Poema Argumentativo en El otro, el mismo (1964)}

Dara el análisis de este poemario proponemos una lectura desde dos modelos retóricos
complementarios: el modelo de análisis basado en la Retórica General Textual del lingüista Stefano Arduini, el cual propone una serie de categorías que trascienden el paradigma limitante formalista de la Retórica restringida, y el modelo de la Retórica de la Argumentación planteados por Chaïm Perelman y Lucie Olbrechts-Tyteca en Tratado de la argumentación. La nueva retórica (1989). Particularmente emplearemos las técnicas argumentativas y nos enfocaremos en explicar su funcionamiento dentro de los poemas de Jorge Luis Borges.

\subsection{Los campos figurativos}

La Retórica como disciplina ha tenido una evolución significativa a lo largo del siglo XX. El paradigma, durante la mayor parte del siglo pasado, fue el de la Retórica restringida, aquella que atendía el estudio único del plano figural. El campo limitado de acción no permitía vincular el estudio de las figuras literarias, (elocutio), con el plano ideológico (inventio) o incluso con el estructural (dispositio), en desmedro de un análisis cabal del texto poético. Ante estas limitaciones en el campo interpretativo, Stefano Arduini propone una serie de categorías que trascienden el paradigma limitante formalista de la Retórica restringida, instituyendo una "neorretórica”: La Retórica General Textual. 
La propuesta de Arduini se construye en base a dos categorías, la de "campo retórico", desarrollada con anterioridad en la unidad 1, y la de "campo figurativo", que explicaremos a continuación. El campo figurativo se constituye como un espacio conceptual que permite la disposición de las distintas figuras literarias en seis categorías de pensamiento. Arduini señala que esta distribución y reordenamiento del "universo figurativo" parte de la clásica propuesta de Giambattista Vico, quien había establecido solo cuatro campos: metáfora, metonimia, sinécdoque e ironía. En el caso de Arduini, él instituye seis campos figurativos: metáfora, metonimia, sinécdoque, antítesis, repetición y la elipsis (2000, p.103).

De acuerdo con la propuesta de la Retórica General Textual, los campos figurativos de Arduini son concebidos como sistemas de pensamiento, en tanto que las figuras transmiten un tipo de conocimiento, el cual involucra y explica la visión del mundo del poeta. Para Arduini, "la figura no hace otra cosa que acoger sobre el plano de la cohesión potencialidades más profundas" (2000, p. 136). Los campos figurativos son, en cierta forma, procesos poéticos que revelan un pensamiento e ideología determinado.

En ese sentido, el análisis retórico debiera articular las figuras literarias, el plano formal, con las estructuras de pensamiento e ideología, el plano discursivo, hacia la develación de las visiones de mundo que albergan los textos poéticos. La interpretación integral que propone Arduini, no se limita a descubrir las formas en el poeta piensa y a organizar el mundo, sino las vincula con los contextos culturales, en los que se inserta y participa.

Volviendo a los campos figurativos, es necesario señalar que dentro de cada una de estas grandes "matrices" conceptuales se ubican un grupo de figuras retóricas. Veamos en detalle:

a) Campo figurativo de la metáfora: la metáfora, propiamente dicha, la alegoría, el símil, el símbolo y la personificación.

b) Campo figurativo de la metonimia: de causa en vez de efecto, de efecto en vez de causa, de continente en vez de contenido, de instrumento en vez del que lo utiliza, de autor en vez de obra.

c) Campo figurativo de la sinécdoque: de la parte en vez de todo, del todo en vez de la parte, de la especie en vez de género, del género en vez de especie.

d) Campo figurativo de la elipsis: la reticencia, la elipsis, propiamente, la perífrasis, el eufemismo, el asíndeton y, por último, el silencio. 
e) Campo figurativo de la antítesis: el oximorón, la antítesis, propiamente dicha, la ironía, la paradoja y el hipérbaton.

f) Campo figurativo de la repetición: la aliteración, la paronomasia, la polisíndenton, la anáfora, la reduplicación, el quiasmo y, por último, la sinonimia.

\subsection{Estructura de El otro, el mismo (1964)}

Publicado en 1964, El otro, el mismo reúne los poemas del autor escritos a lo largo de más de treinta años; desde la aparición en 1929 de Cuaderno San Martín, la única publicación poética del autor fue El hacedor en 1960, aunque este volumen, una miscelánea en palabras del autor, no solo lo integren poemas sino también, relatos y ensayos. En ese sentido, nos hallamos antes un texto importantísimo dentro de la obra poética del autor, que delata el carácter del proceso creador de Borges durante los años en que aparecían, por ejemplo, títulos primordiales como Historia universal de la infamia (1935), Ficciones (1944) y El Aleph (1949).

En palabras del propio autor, El otro, el mismo "no es otra cosa que una compilación”, es decir, no responde a una propuesta temática orgánica preestablecida. En él podemos encontrar una serie de textos que no guardan entre sí una relación de correspondencia marcada por un espacio o tema determinado dentro del poemario. De manera que poemas de diversas temáticas confluyen, se intercalan, a lo largo del volumen sin un orden jerárquico, conceptual o estético propuesto.

Se pueden identificar una serie de líneas temáticas dentro de El otro, el mismo, las cuales han sido desarrolladas ya en libros precedentes como Fervor de Buenos Aires (1923) o Luna de enfrente (1925). Las temáticas más representativas del poemario son el tiempo, el lenguaje, el otro, la historia, el sueño, la muerte, Dios, la memoria, entre otros.

En cuanto a la clasificación de los poemas, podríamos establecer grupos a partir de los ejes temáticos del poemario. No obstante, ninguna clasificación es definitoria toda vez que es arbitraria. En ese sentido, la siguiente propuesta privilegia la selección de los poemas a partir de la identificación del tema principal en una primera lectura. Algunos poemas podrían muy bien ubicarse dentro de otras líneas temáticas, pues, a partir de la lectura que de ellos se hagan, debido a la densidad y complejidad de El otro, el mismo, se puede reconocer dos o más temas en un solo texto. A continuación se detalla la clasificación propuesta: 
Dentro de la temática del sueño podemos ubicar los poemas: "Insomnio", “Lectores”, "El despertar”, “Spinoza”, “Adam Cast Fotrh”, “El sueño”. Dentro de la línea temática del tiempo: "La noche cíclica", "Un soldado de Urbina”, "El tango", "A un poeta sajón”, "Paris, 1856", "El instante”, "Alguien”, "Al hijo”. En el tema de Dios: "Del infierno y del cielo", "Poema del cuarto elemento", “Juan, I, 14”, “Él”, “Jonathan Edwards (17031785)", "El alquimista”. La muerte: "Poema conjetural”, "A una espada en York Minister", “Edgar Allan Poe”, “Los enigmas”, “A quien está leyéndome”, “Una mañana de 1649”. La memoria: "A un poeta menor de la antología", "Página para recordar al coronel Suarez, vencedor en Junín”, “Límites”, “A un poeta menor de 1899”, “Texas, Rafael CansinosAsséns", "Soneto del vino". La patria, la nación o la Argentina cuentan con algunos poemas dedicados exclusivamente a su reflexión, como: "Mateo, XXV, 30", "Sarmiento", "Oda escrita en 1966", "Buenos Aires", "Los compadritos muertos". Dentro de la temática del lenguaje o la palabra encontramos a los poemas: "Una brújula", "Un poeta del siglo XIII”, “Baltazar Gracián”, “El Golem”, “Una rosa y Milton”, “Composición escrita en un ejemplar de la gesta de Beowulf". Sobre la historia: "Una llave en Salónica", "Un sajón”, "Fragmento", "Al vino", "El hambre”. Sobre el tema del otro: "El otro", "Alexander Selkirk", "Odisea, libro vigésimo tercero", "Emerson”, "Camden, 1892”, "El forastero", "Edipo y el enigma”, "Elegía”, "A una moneda", “Junín”. El tema del espejo es abordado en: "A quien ya no es joven" y "Edipo y el enigma". En cuanto al olvido, podemos identificar los poemas: “A Carlos XII, 1964”, “Everness", "Ewigkeit”, “Un soldado de lee (1862)” y "A un poeta sajón". Mención aparte merece "Otro poema de los dones", pues es una suma de todos los temas en torno a los cuales reflexiona Borges a lo largo de su obra.

\subsection{Análisis de "Composición escrita en un ejemplar de la Gesta de Beowulf”}

COMPOSICIÓN ESCRITA EN UN EJEMPLAR DE LA GESTA DE BEOWULF

1 A veces me pregunto qué razones

2 Me mueven a estudiar sin esperanza

3 De precisión, mientras mi noche avanza,

4 La lengua de los ásperos sajones.

5 Gastada por los años la memoria 
6 Deja caer la en vano repetida

7 Palabra y es así como mi vida

8 Teje y desteje su cansada historia.

9 Será (me digo entonces) que de un modo

10 Secreto y suficiente el alma sabe

11 Que es inmortal y que su vasto y grave

12 Círculo abarca todo y puede todo.

13 Más allá de este afán y de este verso

14 Me queda inagotable el universo.

Como complemento del modelo propuesto por Arduini, emplearemos los conceptos básicos de la Retórica de la Argumentación planteados por Chaïm Perelman y Lucie Olbrechts-Tyteca en Tratado de la argumentación. La nueva retórica (1989). Particularmente, nos enfocaremos en las técnicas argumentativas y su funcionamiento dentro de los textos literarios, en este caso en los poemas de Jorge Luis Borges.

Chaïm Perelman y Lucie Olbrechts-Tyteca clasifican las técnicas argumentativas en cuatro grupos: 1) los de argumentación cuasi-lógica (que se aproximan a la formalización del pensamiento) 2) los argumentos basados en la estructura de lo real (conforme a la naturaleza misma de las cosas), 3) los argumentos que tienden a fundamentar la estructura de lo real ( que se basan en el caso particular y en la analogía), 4) los de disociación de nociones (que tienden a desintegrar las nociones aceptadas).

Para el siguiente análisis argumentativo se tendrán en cuenta cuatro niveles interpretativos y un análisis interdiscursivo. En primera instancia se estratifican la tesis del poema y las partes del discurso argumentativo: el exordio, la narración, la argumentación y la peroración. En el segundo nivel se reconocen y explican las provincias figurales. En un tercer nivel se identifican los elementos pragmáticos de la comunicación poética: el locutor y el alocutario. En un cuarto nivel, se analiza la visión del mundo que se presenta en el poema. Finalmente, se propondrá un análisis interdiscursivo, el cual nos permitirá profundizar en la propuesta poética del poemario.

\subsubsection{Las partes del texto argumentativo}

Las partes del texto argumentativo son cuatro: el exordio, la narración, la argumentación y la peroración. En este poema, el exordio va del primer verso al cuarto, 
a esta sección la titulamos "La resignación ante lo incognoscible". Este segmento tiene la función de abrir el cuestionamiento sobre la inutilidad de la lengua o lenguaje. Según el poeta, él es consiente de que dedicar su vida al aprendizaje del lenguaje es inútil, ni él, ni la tradición que lo precede, ha logrado descifrar lo "real" que escapa a la escritura. El segundo segmento corresponde a la argumentación, la cual comprende del verso quinto al decimosegundo, a este segmento denominamos "La inmortalidad del alma transita fuera del lenguaje". Se expone que la escritura es un acto metódico y monótono, pues se lleva a cabo en el mundo material que es finito. Sin embargo, el alma, es parte del mundo ideal que trasciende el lenguaje, por lo tanto solo ella puede acceder a lo real. Finalmente, la tercera parte del poema es la peroración, ella está compuesta por los dos versos finales, el verso decimotercero y el decimocuarto; a esta sección titulamos "El encuentro con lo real". Los últimos versos plantean la conclusión a la que llega el poeta, es una certeza; tras la muerte, el alma supera al lenguaje, pues ella puede alcanzar lo real en la inmortalidad.

Un aspecto interesante que vale la pena señalar es el título, el cual alude al histórico cantar de Gesta de Gesta de Beowulf, en claro diálogo con la tradición literaria anglosajona.

Estas partes sostienen una tesis a lo largo de su estructura, en este caso la tesis del autor que proponemos para este poema es la siguiente: El estudio del lenguaje, o la palabra, es inútil, pues este es incapaz de representar lo real, el cual excede los límites del lenguaje.

\subsubsection{Los campos figurativos}

A lo largo del poema podemos identificar diversos campos figurativos. El primero, el campo figurativo de la metáfora, provincia figura de la personificación: “(...) y es así como mi vida/ teje y desteje su cansada historia”. La vida adquiere un carácter animado que reemplaza incluso al locutor del poema, ejerciendo el protagonismo en el texto pues es quien ejecuta la acción principal: tejer y destejer la historia del poeta. El segundo campo figurativo es la metonimia, provincia figural -de efecto en vez de causa: "gastada por los años la memoria", aquí se da preponderancia al tiempo como ejecutante del desgastamiento de la memoria. En El otro, el mismo el tiempo es una temática que recorre todo el poemario; como en otros poemas, Borges relaciona la indefectibilidad del tiempo con la fatalidad del olvido.

En cuanto al campo figurativo de la sinécdoque, encontramos la provincia figural -de la parte en vez del todo: "Más allá de este afán y de este verso (...)", en donde verso ocupa el lugar del poema. Es importante que en la peroración Borges utilice el "verso" 
para referirse a la inutilidad del poema como medio expresivo de lo real, lo cual establece, consecuentemente, una relación con la inutilidad del propio lenguaje, que termina siendo la tesis que se plantea en el poema. En el campo figurativo la repetición, encontramos la provincia figural de polisíndeton: "Secreto y suficiente el alma sabe/ Que es inmortal y que su vasto y grave/ Círculo abarca todo y puede todo", la repetición de la "y" tiene un carácter rítmico en el poema, además permite adicionar todas las posibilidades y niveles de los que el "alma” es consiente tiene por naturaleza. La repetición solo reitera la complejidad del alma humana, la cual la aproxima a lo real, aquello que está fuera de "este verso", aquello que está en el "inagotable universo".

Finalmente tenemos el campo figurativo de la antítesis, con la provincia figural de la antítesis propiamente: en "teje y desteje su cansada historia” (contraste/oposición/ antónimos). La antítesis en este verso busca focalizar el absurdo de la existencia del hombre; el trabajo de la vida, que en el verso se lee como "el tejer y destejer" su propia historia, señala la inutilidad y la incongruencia de la vida frente al tiempo y ante el advenimiento inequívoco de la muerte.

\subsubsection{Los interlocutores}

En el poema se presenta un locutor personaje que monologa ante un posible alocutario. Esto se puede constatar al inicio del poema cuando el locutor advierte su soliloquio: "A veces me pregunto qué razones (...)". Por otro lado, el poema presenta un alocutario no representado, pues no se señala una segunda persona a quien estaría dirigido el mensaje del texto. La elección por un locutor personaje que monologa, atiende al hecho de que Borges está considerando en el poema que las reflexiones existencialistas en torno a la vida, el tiempo, la imposibilidad de aprehender y/o acceder a lo real, el advenimiento de la muerte como destino inequívoco, son propias de la conciencia que tiene el hombre de su propia soledad en el mundo.

\subsubsection{Las técnicas argumentativas}

Dentro de las técnicas argumentativas que podemos identificar en este poema se encuentran, en primer lugar, los Argumentos cuasilógicos, dentro de ellos el Argumento de probabilidad: "Será (me digo entonces) que de un modo/ Secreto y suficiente el alma sabe/ Que es inmortal y que su vasto y grave/ Círculo abarca todo y puede todo". Este 
argumento es empleado para crear una incertidumbre en lugar de establecer una afirmación; en este caso Borges relega las reflexiones metafísicas al plano hipotético. Por otro lado, encontramos el Argumento por comparación: "Gastada por los años la memoria/ Deja caer la en vano repetida/ Palabra y es así como mi vida/ Teje y desteje su cansada historia” En este argumento se presenta el conector comparativo "así como", a partir del cual se establece la relación comparativa entre dos enunciados: El que la memoria deje caer la palabra repetida en vano se compara al hecho de que la vida teja y desteja su historia cansada. A partir de la antítesis identificada en "teje y desteje", podemos reconocer que la comparación entre ambas situaciones en el poema responden a vincular ambas al absurdo, lo incongruente y señalar, finalmente, su inutilidad.

En cuanto a los Argumentos basados sobre la estructura de lo real, encontramos al Argumento sobre la estructura de lo real (por nexo de sucesión) en los versos "Será (me digo entonces) que de un modo/ Secreto y suficiente el alma sabe/ Que es inmortal y que su vasto y grave/ Círculo abarca todo y puede todo" en realidad se expresaría (Será (me digo entonces) que de un modo/ Secreto y suficiente el alma sabe/ Que es inmortal y que (por tanto) su vasto y grave/ Círculo abarca todo y puede todo). Se inserta un conector consecuencia/ nexo de sucesión que se ha omitido en el poema para dar énfasis a la intención argumentativa que subyace en el verso; entre ambos enunciados se establece una causa y consecuencia, está ultima se presenta de manera concluyente a partir del conector omitido "por tanto".

\subsubsection{Visión de mundo}

A partir del cuestionamiento sobre la utilidad de conocer, aprender, dominar el lenguaje, entiéndase la palabra, el poeta concluye que, finalmente, esto no es una preocupación mayor, pues lo real, la verdad, que esta fuera del lenguaje, es hacia donde la muerte algún día lo llevará. Esta visión se condice con el pensamiento idealista tan presente en la poética de Borges, en el cual el mundo se entiende como una representación solipsista de lo real, que es inaprensible. Borges entiende la escritura como una copia de un modelo determinado por la percepción del hombre, de manera que aprehender lo real está fuera de las capacidades del lenguaje y del propio ser humano. Tanto lo real como el propio yo es inexistente para Borges, ambas son presencias cuya cognocibilidad es imposible. 


\subsubsection{Análisis interdiscursivo}

Para el análisis comparativo de este apartado, hemos escogido el poema "brújula", dedicado a Esther Zemborain de Torres, también del poemario El otro, el mismo de Borges. El poema presenta predominantemente el campo figurativo de la metáfora: se puede identificar la metáfora propiamente dicha en los versos: "esta agonía/De ser enigma, azar, criptografía/Y toda la discordia de Babel”. Aquí el poeta establece una relación identitaria entre el "ser" del hombre y el "enigma", adjudicando las características del segundo en el primero; el hombre es un misterio, una interrogante sin respuesta. Además, encontramos el uso de la personificación: "Detrás del nombre hay lo que no se nombra;/ Hoy he sentido gravitar su sombra/ En esta aguja azul, lúcida y leve,/ Que hacia el confín de un mar tiende su empeño (...)". En estos versos, la sombra de "aquello que no puede ser nombrado", tiene autonomía, pues se desplaza hacia el mar con empeño. El uso de la personificación le otorga carácter de actor dentro del poema a "eso" que resulta innombrable. Al igual que en el poema "Composición escrita en un ejemplar de la gesta de Beowulf", Borges reconoce que existe una instancia que está al margen de la palabra, que lo real habita fuera de la escritura $\mathrm{y}$ es inasible pero potente, tanto que tiene capacidad de actuar a las orillas de las palabras.

En cuanto al uso de las técnicas argumentativas, la identificación de los campos figurales nos permite extender y profundizar el análisis comparativo. En este caso, la técnica argumentativa por la que Borges se inclina es la del argumento por definición. En el exordio, el cual está conformado por los primeros cuatro versos podemos identificar dos definiciones: "Todas las cosas son palabras del/ Idioma en que Alguién o Algo, noche y día, / Escribe esta infinita algarabía/ Que es la historia del mundo". La primera definición relaciona las "cosas" con las "palabras", en ese sentido, Borges recurre a la enfatización de que la realidad, es susceptible de ser representada por el lenguaje. Por otro lado, la segunda definición propone la relación identitaria entre "infinita algarabía" e "historia del mundo"; sin embargo, esta correspondencia está supeditada por la "escritura". Cuando Borges menciona "mundo", se está refiriendo al mundo perceptible, el cual es representado por el lenguaje. En el poema, Borges plantea nuevamente la resignación del hombre ante la imposibilidad de conocerse, pues el alma habita el lugar de lo real, aquel en el cual la palabra no tiene competencia.

\subsection{Análisis de "El mar"}




\section{EL MAR}

1 Antes que él sueño (o el terror) tejiera

2 Mitologías y cosmogonías,

3 Antes que el tiempo se acuñara en días,

4 El mar, el siempre mar, ya estaba y era.

5 ¿Quién es el mar? ¿Quién es aquel violento

$6 \mathrm{Y}$ antiguo ser que roe los pilares

7 De la tierra y es uno y muchos mares

8 Y abismo y resplandor y azar y viento?

9 Quien lo mira lo ve por vez primera,

10 Siempre. Con el asombro que las cosas

11 Elementales dejan, las hermosas

12 Tardes, la luna, el fuego de una hoguera.

13 ¿Quién es el mar, quién soy? Lo sabré el día

14 Ulterior que sucede a la agonía.

\subsubsection{Las partes del texto argumentativo}

En el poema "Mar", el exordio está comprendido por los versos primero, segundo, tercero y cuarto, a esta sección la titulamos "El primigenio mar". Este segmento tiene como función presentar la naturaleza del mar de acuerdo con la poética de Borges. Se expone la naturaleza antediluviana del mar, su estado puro e incorruptible. El segundo segmento es el de la argumentación, el cual se extiende desde el verso quinto hasta el decimosegundo, al cual denominamos "El cuestionamiento del mar". En este segmento se explica, a través de múltiples preguntas la omnipresencia del mar; sin embargo, también se sugiere el perfil contemplativo del hombre, para quien es incognoscible a cabalidad. Por último, la tercera parte es la peroración, la cual comprende los versos decimotercero y decimocuarto, a este segmento titulamos "La inmortalidad del mar". Estos versos develan la trascendencia del mar y su simbología; se ubica en las afueras del mundo sensible, en el mundo ideal, al que las representaciones por medio del arte y del lenguaje, no pueden alcanzar, pues solo el alma, liberada del cuerpo, llegará a su eternidad. 
Estos tres segmentos, a lo largo de su desarrollo, soportan una tesis: El poeta busca comprender inútilmente al mar, pues sabe que solo conocerá su esencia, tras la muerte, cuando retorne a lo trascedente.

\subsubsection{Los campos figurativos}

El poema presenta una variedad de campos figurativos; sin embargo, la predominancia es del Campo figurativo de la metáfora, en particular de la personificación. En el exordio, podemos identificar "Antes que el sueño (o el terror) tejiera/ Mitologías y cosmogonías", a partir de esta personificación podemos advertir el carácter animado que adquiere el sueño. En el poema, el sueño no solo tiene una representación de autonomía, sino, además, de poder; "tejiera mitologías y cosmogonías”. Según Borges, el sueño es el supremo artífice de los grandes relatos de la antigüedad. Por otro lado, habría que analizar también el uso del verbo "tejer" y su origen etimológico latino "texere", sin prescindir de su raíz indoeuropea "teks", relacionado con la técnica. Borges, conocedor de estas lenguas, utiliza este verbo no por sencilla casualidad; según lo expuesto, el sueño estaría relacionado con el empleo de la técnica representativa, la cual es, por antonomasia, la escritura y, en un plano genérico, el lenguaje articulado. Otro elemento fundamental que es personificado en el poema es "el mar":

¿Quién es el mar? ¿Quién es aquel violento

$\mathrm{Y}$ antiguo ser que roe los pilares

De la tierra y es uno y muchos mares (...)

A pesar de que la personificación esté en clave de pregunta, se presenta una afirmación dentro de la misma acerca de la naturaleza del mar. El mar adquiere la capacidad de "roer"; lo que evidencia que, al igual que el sueño, este elemento también es omnipotente dentro de la propuesta del poema.

Respecto del campo figurativo de la antítesis, encontramos a la antítesis propiamente en el siguiente verso, "El mar, el siempre mar, ya estaba y era". La contradicción en el verbo estar que intenta ser conjugado con "el mar", nos indica la complejidad que posee este elemento para el poeta; el mar pertenece a un tiempo pasado, pero también habita en el presente, es simultaneo y, por ello omnipresente. Lo mismo ocurre con "antiguo ser 
que roe los pilares/ De la tierra y es uno y es muchos mares", esta antítesis enfatiza en la inconmensurabilidad y la universalidad del mar, aproximándolo a lo que sería el arquetipo.

Finalmente, Borges no descuida la musicalidad; dentro del campo figurativo de la repetición, emplea el polisíndenton: "antiguo ser que roe los pilares/ De la tierra y es uno y es muchos mares / y abismo y resplandor y azar y viento". Sin embargo, este uso no solo detenta un carácter musical o, erróneamente señalado como "decorativo"; el uso reiterado de la conjunción "y", es utilizado para la enumeración de las diversas formas que adquiere el "mar". Ello enfatiza en la multiplicidad de su naturaleza y su, nuevamente señalamos, omnipresencia.

\subsubsection{Los interlocutores}

En "El mar", podemos identificar un locutor personaje representado que ejecuta un monólogo. El poema es un acto comunicativo reflexivo; él es quien emite el discurso para sí mismo, “¿Quién es el mar, quién soy yo?” En ese sentido, el poema presenta un alocutario no representado. El uso de esta fórmula de emisor y receptor en el sistema comunicativo en Borges, es frecuente; ello debido a que gran parte de su poesía posee un tono reflexivo y en muchos de sus poemas, incluso, él es un personaje más. De ello podría deducirse que Borges produce poesía para sí mismo. Aunque por lo que hemos podido analizar de su poética, él mismo es todos y cada uno de los hombres.

\subsubsection{Las técnicas argumentativas}

$\mathrm{Al}$ tratarse de un poema breve, las técnicas argumentativas pueden ser empleadas en un mismo conjunto de versos, o un verso puede ser usado para dos técnicas argumentativas diferentes, lo cual no resulta contradictorio, pues ello solo evidencia el grado de complejidad de la poesía de Jorge Luis Borges. En relación a los argumentos cuasilógicos, que son los más abundantes, encontramos el argumento por definición:

Antes que él sueño (o el terror) tejiera

Mitologías y cosmogonías,

Antes que el tiempo se acunara en días,

El mar, el siempre mar, ya estaba y era. 
Chaïn Perelman señala que "(...) las definiciones buscan tratar al término definido y la expresión que lo define como intercambiables" (1998, p. 90). En ese sentido, la definición de "mar" como una presencia tanto pasada como futura, enfatiza en la simultaneidad de su naturaleza, pero sobre todo, según la definición de Perelman, debido a que la definición plantea términos de equivalencia, "mar" no solo sería una entidad sincrónica, "el mar" sería el propio tiempo. A ello habría que agregar a los enunciados (versos) que anteceden la definición que de alguna manera la soportan. El mar era el tiempo desde antes que "el sueño", otro personaje del poema, tejiera, los grandes relatos, antes que el tiempo, el mismo, se contabilizara. Otro argumento cuasilógico es el de justicia y reciprocidad:

¿Quién es el mar? ¿Quién es aquel violento

$\mathrm{Y}$ antiguo ser que roe los pilares

De la tierra y es uno y muchos mares

Y abismo y resplandor y azar y viento?

Los argumentos basados en justicia e igualdad presentan una estructura particular en función de su objetivo argumentativo. Según Perelman (1998), este principio evidencia una regla de justicia de carácter eminentemente formal. De acuerdo con esta, a los seres que pertenecen a una misma categoría esencial, deben ser tratados de la misma manera. En este caso, los seres que se establecen como parte de una misma categoría son "el mar", "abismo", "resplandor", “azar" y "viento". Lo que permite este tipo de argumento es exponer la naturaleza del término a equiparar; "el mar" adquiere la misma esencia que todos los elementos mencionados. El común denominador de esta relación tendría que ver con que todos elementos son, en términos de Kant, "sublimes".

Por otro lado, también podemos encontrar el argumento por analogía: “¿Quién es el mar, quién soy yo? Lo sabré el día/ ulterior que sucede a la agonía”. Este tipo de argumentos tienen el objetivo de establecer un vínculo de semejanza entre enunciados distantes. Al respecto, Perelman señala: "Ella difiere de la proporción puramente matemática en tanto que no plantea la igualdad de dos relaciones, sino que afirma una semejanza de relaciones" (1998, p. 154). En los versos expuestos, la analogía es muy sutil; sin embargo, es reconocible la relación de semejanza que se pretende articular entre la identidad del mar y la identidad del poeta. Al formular dos preguntas en un solo enunciado se establece cierta relación de 
equidad, ello por el aspecto formal. En cuanto al discursivo, el poema se ha enfocado en discutir con una falsa molestia acerca de la naturaleza del mar, es decir, mientras el poeta formulaba sus preguntas respecto de la naturaleza del mar, al mismo tiempo respondía y afirmaba sus características. Al término del poema, se revela que la trascendencia del mar, cuya denominación se ha construido a lo largo del poema, es compartida por el poeta, quien no es otro que el hombre. Por ello, el mar, quien es lo trascendente, el arquetipo, lo universal, lo inefable, lo real, puede solo encontrase a las afueras de la vida finita del hombre. Para que este acceda a lo trascendente, tendría que abandonar su mortalidad; el alma se liberaría por medio de la muerte.

\subsubsection{Visión de mundo}

El poema expone la búsqueda por comprender el mar, a pesar de que en medio de los cuestionamientos, se planteen las respuestas solicitadas. El mar se construye como lo trascendente; particularmente, no se trata en esta ocasión de un elemento que habita el mundo de las ideas, como el ruiseñor. El mar se presenta como el mismo mundo ideal, de allí la imposibilidad del lenguaje de nombrarlo; es inefable. Esta entidad, o este todo, es al que Borges interpela constantemente en sus poemas y reflexiona acerca de los modos con los que el hombre, a través de la poesía, lo ha intentado aprehender. La muerte, como la única certeza del hombre, sería el camino natural y directo hacia esa instancia con la cual comparte la misma naturaleza e identidad.

\subsubsection{Análisis interdiscursivo}

Creemos que para un análisis comparativo de "El mar", los versos del "Poema del cuarto elemento" son más que certeros. El poema también es parte de El otro, el mismo, de manera que puede entenderse la íntima relación entre ambos textos. Para explicar ello, es necesario citar los siguientes versos:

El mar y la moviente montaña que destruye

A la nave de hierro sólo son tus anáforas,

Y el tiempo irreversible que nos hiere y que huye,

Agua, no es otra cosa que una de tus metáforas. 
Tal como en "El mar", en "Poema del cuarto elemento", Borges insiste en la reflexión en torno al mundo ideal, lo real, que habita en las afueras del lenguaje. Esta vez, establece una relación interesante entre "mar" y "agua"; mientras el mar es poderoso, destruye el tiempo; el agua solo es una "metáfora". Lo que el poeta parece explicar es, nuevamente, la oposición entre mundo sensible y mundo ideal. Bajo este antagonismo de esferas; el mar pertenecería, es, el mundo ideal; mientras que el agua vendría a ser la representación del primero en el mundo sensible.

En los versos siguientes, el poeta se concentra en la definición del "agua" para, al parecer, desligarla de "mar":

Brillas como las crueles hojas de los alfanjes, Hospedas, como el sueño, monstruos y pesadillas.

Los lenguajes del hombre te agregan maravillas

Y tu fuga se llama el Éufrates o el Ganges.

(Afirman que es sagrada el agua del postrero, Pero como los mares urden oscuros canjes

Y el planeta es poroso, también es verdadero

Afirmar que todo hombre se ha bañado en el Ganges)

Los versos "Los lenguajes del hombre te agregan maravillas", confirmarían la constitución representacional que define al "agua", en contraposición de "mar". Por otro lado, considera necesario indicar que a pesar de la corrupción del lenguaje, lo real, el mundo ideal, es una entidad porosa, por medio de la cual, a través de distintas estrategias (la poesía, el arquetipo, la muerte), el hombre puede acceder a él en cierto grado y medida: "Pero como los mares urden oscuros canjes/Y el planeta es poroso/ también es verdadero/Afirmar que todo hombre se ha bañado en el Ganges". Ello sería posible porque, como se mencionó en el análisis al poema "El mar", el hombre y el mundo ideal, comparten la misma naturaleza.

\section{Las Metáforas y Técnicas Argumentativas en El otro, el mismo}

E n el siguiente apartado, nos enfocaremos en el desarrollo del modelo teórico propuesto por George Lakoff y Mark Johnson en el clásico Metáforas de la vida cotidiana (1980). 
Seguidamente, bajo este modelo, desarrollaremos dos análisis. El primero sobre "Un poeta del siglo XIII" y el segundo sobre "Una rosa y Milton”

\subsection{Tipos de metáfora}

En Metáforas de la vida cotidiana, Lakoff y Jonhson reflexionan sobre el carácter metafórico del lenguaje cotidiano. Contrario a lo que se suele pensar, las metáforas “impregnan la vida cotidiana, no solamente el lenguaje, sino también el pensamiento y la acción" (Lakoff y Johnson, 1980, p. 39). El lenguaje evidencia nuestro sistema conceptual, las metáforas, en ese sentido, lo articulan. Es decir, nosotros construimos nuestra visión de mundo a partir de metáforas. Veamos a continuación los tres tipos de metáforas que identifican Lakoff y Johnson.

\subsubsection{Metáforas estructurales}

Las metáforas estructurales permiten que un concepto esté estructurado metafóricamente en términos de otro. Es decir, podemos comprender un rasgo del concepto en función de otro concepto, ya que proyectamos sus características en él. Un ejemplo clásico es "una discusión es una guerra"

\subsubsection{Metáforas orientacionales}

Las metáforas orientacionales no estructuran un concepto en términos de otro, como sucede con las metáforas estructurales. Las orientacionales o espaciales, organizan un sistema global de conceptos teniendo en cuenta las oposiciones espaciales: arriba - abajo, dentro - fuera, delante - detrás, centro - periferia. Un ejemplo es "feliz es arriba”, ya que relaciona el concepto de "felicidad" con la coordenada "arriba". De manera que podemos decir, metafóricamente: "Me levantó los ánimos” y entendemos que la relación de "ánimos" con "arriba" es siempre positiva.

\subsubsection{Metáforas ontológicas}

Las metáforas ontológicas nos permiten visualizar una cosa no física en función de una entidad o sustancia. Lakoff y Johnson sostienen que "nuestras experiencias con objetos físicos (...) proporcionan la base para una variedad extraordinariamente amplia de metáforas 
ontológicas, es decir, formas de considerar acontecimientos, actividades, emociones, ideas, etc., como entidades o sustancias" (1980, p.64). Ejemplo: "La mente es una máquina”.

\subsection{Análisis de "Un poeta del siglo XIII"}

\section{UN POETA DEL SIGLO XIII}

1 Vuelve a mirar los arduos borradores

2 De aquel primer soneto innominado,

3 La página arbitraria en que ha mezclado

4 Tercetos y cuartetos pecadores.

5 Lima con lenta pluma sus rigores

6 Y se detiene. Acaso le ha llegado

7 Del porvenir y de su horror sagrado

8 Un rumor de remotos ruiseñores.

9 ¿Habrá sentido que no estaba solo

10 Y que el arcano, el increíble Apolo

11 Le había revelado un arquetipo,

12 Un ávido cristal que apresaría

13 Cuanto la noche cierra o abre el día:

14 Dédalo, laberinto, enigma, Edipo?

\subsubsection{Las partes del texto argumentativo}

Para la segmentación de este poema, identificamos las partes del texto argumentativo. El exordio estaría comprendido desde el primer verso hasta el cuarto, al cual titulamos "La inutilidad de la escritura”. En esta sección se presenta el cuestionamiento de la escritura, ella es insuficiente para expresar la emoción verdadera del poeta pues, a pesar de las innumerables enmendaduras, los versos siguen siendo "pecadores", es decir, transgresores de una naturaleza "pura" a la cual no pueden alcanzar. La narración estaría comprendida desde el verso quinto al decimosegundo, al cual titulamos "La aproximación a lo inefable". 
Esta sección corresponde al relato del proceso creativo que atraviesa el poeta. La escritura se presenta como un trabajo arduo y complejo. El poeta se enfrenta a la resistencia del el lenguaje para aproximarse a la "verdad"; sin embargo, es consciente de que puede acceder a ella, en cierto grado, gracias a la intervención de alguna deidad como Apolo. Solo a través de un dios, aquella "verdad" puede ser develada. De la cual entendemos, transita en esfera inaccesible para el poeta y sus palabras. En cuanto a la peroración, ella estaría comprendida por el verso decimotercero y el decimocuarto, a esta sección la denominaremos "El encuentro con la verdad". En este breve segmento, se exponen las condiciones en las que el poeta puede llegar a acceder a algún resquicio de lo inefable. Entre el día y la noche, es decir, en el sueño, la eterna búsqueda por descifrar el enigma de lo inaprensible se lleva a cabo. Antes de él, Dédalo y Edipo, emprendieron la misma tarea.

La tesis del autor que proponemos para este poema es la siguiente: Lo real se puede filtrar en la escritura a pesar de sus limitaciones.

\subsubsection{Tipos de metáfora}

En "Un poeta del siglo XIII", las metáforas predominantes son las orientacionales; la poética de Borges privilegia las referencias espaciales, evidencia a través de ellas, quizá, la búsqueda incansable de la "palabra mágica", tal como señala es su propósito en el prólogo de El otro, el mismo. Este tipo de metáforas no construyen un concepto en términos de otro, sino más bien organizan un sistema global de conceptos en función de otro (Lakoff y Johnson, 1980). En ese sentido, en la metáfora que quisiéramos destacar, "La página arbitraria en que ha mezclado/ Tercetos y cuartetos pecadores", al mencionar "en" se está determinando, implícitamente, la oposición entre dos espacios; el adentro o interior de la página y el afuera o exterior de la misma. No se está construyendo un nuevo sentido desde un término, sino que, presentar la oposición entre dos esferas, permite visualizar las los campos semánticos que se articulan a partir de las distancias espaciales de una respecto de la otra. En este caso, "página arbitraria" constituye el interior, en ella se "mezclan tercetos y cuartetos pecadores". La caracterización de "arbitrario", revela la perversión de este espacio en el cual se hallan elementos corruptos como los "tercetos y cuartetos pecadores". Borges plantea la construcción de una esfera exterior a partir de la representación de su antagónico; la página corrupta. La poesía, según Borges, se halla en el claustro corrupto de la escritura; su finitud y decadencia están determinados por la traición (pecadores) del lenguaje, a través de la representación fallida, de lo real, aquello que está afuera de su alcance y que, 
por oposición, sería el espacio de la pureza y la "verdad". No es casual que está metáfora categórica se ubique en el exordio del poema, la cual se titula "La inutilidad de la escritura". Borges plantea los principios de su poética que regirán la propuesta del poema.

La segunda metáfora orientacional que identificamos, pertenece a la narración, el segmento titulado "La aproximación a lo inefable". En este caso, la metáfora determina la oposición espacial entre centro y periferia: "Un rumor de remotos ruiseñores". A partir de ella, Borges establece dos esferas; la céntrica, lugar en el que se haya el poeta; y la periférica, en donde se encuentran los "ruiseñores". A diferencia de la primera figura, en la que el poeta construye la esfera exterior en función de la representación de la interior; aquí la periferia será la que, desde cuyo sistema de conceptos, construya a su opuesto. Para ello, habría que rastrear la simbología del ruiseñor en la poesía de Borges; brevemente señalaremos que una relevante aparición del ruiseñor como tema en la obra del argentino, ocurre en 1952 con Otras inquisiciones, se trata del ensayo "El ruiseñor de Keats". Una lectura desde Schopenhauer, le otorga al autor la lucidez para comprender la propuesta de Keats; el texto, a su vez, no deja de ser un importante documento en el que Borges evidencia las influencias filosóficas y estéticas de su obra:

Keats, que sin exagerada injusticia pudo escribir: "No sé nada, no he leído nada”, adivinó, a través de las páginas de algún diccionario escolar, el espíritu griego; sutilísima prueba de esa adivinación o recreación es haber intuido en el oscuro ruiseñor de una noche el ruiseñor platónico. Keats, acaso incapaz de definir la palabra arquetipo se anticipó en un cuarto de siglo a una tesis de Schopenhauer. (1989, p. 96)

Por otro lado, en 1975 aparece La rosa profunda, en el cual hallamos el poema "Al ruiseñor"; en particular, quisiéramos destacar los versos: “Un espíritu errante fue tu símbolo/ En un libro de enigmas". El ruiseñor en la obra de Borges está íntimamente relacionado con lo universal, el arquetipo, aquello que transita en la esfera de lo real, lo inmortal y, por tanto, opuesto a la vida efímera del hombre. En el verso "Un rumor de remotos ruiseñores", la periferia es espacio incierto en el que descansa el ruiseñor y que llega al centro, la vida del hombre, trayéndole la verdad. El ruiseñor es un arquetipo, un vehículo de lo real.

Encontramos también una metáfora ontológica significativa: "Le había revelado un arquetipo, / Un ávido cristal que apresaría”. Las metáforas ontológicas tienen como 
función permitirnos establecer relaciones entre una cosa no física y una entidad y sustancia. Se trata de una figura del lenguaje que permite aproximarnos a comprender definiciones y conceptos dentro de una poética determinada. En ese sentido, los versos expuestos están asociados desde una correspondencia entre arquetipo y cristal, en donde el arquetipo adquiere la característica fundamental del cristal, la fragilidad. A ello podríamos adicionar la transparencia asociada con la pureza, o la virtud de reflejar su entorno por ser de una superficie lisa, logrando así asemejarse al espejo, símbolo preponderante en la poética borgiana.

\subsubsection{Los interlocutores}

En el poema "Un poeta del siglo XIII", identificamos un locutor personaje no representado. Por otro lado, no se presenta con claridad la figura de un alocutario. A pesar de que el alocutario formula preguntas dirigidas, no se determina hacia quien están destinadas. En todo caso, podríamos considerar el texto como un monólogo. Otro aspecto a señalar es que el poema es de tendencia narrativa, desde esa perspectiva, el alocutario actúa como un narrador "omnisciente" dentro del texto, pues él quien relata los hechos.

\subsubsection{Técnicas argumentativas}

El poema presenta una multiplicidad de técnicas argumentativas, en función de la tesis, Lo real se puede filtrar en la escritura a pesar de sus limitaciones, el autor despliega a lo largo del texto distintos tipos de técnicas que revisaremos a continuación.

Respecto de los argumentos cuasilógicos, identificamos el argumento de división. En el exordio, de título "La inutilidad de la escritura", podemos reconocerlo: "Vuelve a mirar a los arduos borradores/ De aquel primer soneto innominado, / La página arbitraria en que ha mezclado/ Tercetos y cuartetos pecadores”. Según Perelman:

El argumento por división, cuya utilización puede servirnos no solo como prueba, sino también como medio para crear la presencia por la enumeración de las partes (...), está a la base del dilema, así como de razonamientos a pari y a contrario. En el dilema se examinan dos eventualidades para concluir que ambas conducen a una consecuencia desagradable. (1998, p.104) 
En el caso de la metáfora por división expuesta, se plantea que tanto los versos "Vuelve a mirar a los arduos borradores/ De aquel primer soneto innominado" como "La página arbitraria en que ha mezclado/ Tercetos y cuartetos pecadores". Evidencian dos aspectos señalados por Perelman como característica de este tipo de argumentos. Son partes enumeradas que no se relacionan en función de oposición, sino de complementariedad; y ambas son eventualidades que conducen a una consecuencia desagradable, ambas exponen la corrupción del lenguaje como medio expresivo, bien por la dificultad de lograr representar lo inefable, o porque cuando se logra alguna representación, esta es traidora de la pureza que intenta capturar.

En cuanto a los argumentos basados sobre la estructura de lo real, podemos reconocer el argumento por nexo de coexistencia: "Lima con lenta pluma sus rigores" en los versos iniciales de la narración. Según Perelman:

(...) los nexos de coexistencia establecen un lazo entre realidades de desigual nivel de las cuales la una se presenta como la expresión o manifestación de la otra, tal como la relación de una persona y sus acciones, sus juicios o sus obras. (1998, p. 123)

En este caso, el poeta constituye un vínculo entre la materialidad de la pluma y su "lento limar" y la idealidad de los "rigores", de manera que el segundo adquiere corporeidad a partir del primero. El poeta utiliza esta estrategia para enfatizar en la rigidez del lenguaje a ser sometido, lo relaciona con algún elemento recio que pone resistencia a expresar lo real. De allí la necesidad de destacar "Lima con lenta pluma"; de alguna manera describe, a su vez, el oficio del poeta.

Otro argumento importante es el de autoridad, el cual se presenta en verso decimoprimero: "Y que el arcano, el increíble Apolo/ Le había revelado un arquetipo". Sobre este argumento, Perelman indica: "El prestigio de una persona o de un grupo de personas se utiliza para hacer admitir una tesis" (1998, p. 128). Decíamos que este argumento es particularmente relevante porque Borges utiliza la figura de Apolo (cuya llegada versos atrás era precedida por el ruiseńor) para resaltar la procedencia del arquetipo. No es casual que el "increíble Apolo", identificado con la verdad, dios de la música y la poesía, sea quien tenga en su poder el arquetipo, portador de la universalidad. Borges plantea, nuevamente, 
que la esfera de lo real, lo puro, lo inefable, la verdad, se encuentra en un estado al cual no podemos acceder sino por medio de los dioses. En ese sentido, de alguna manera, Borges, retomaría en este poema el mito griego de la inspiración por las musas.

Encontramos, también, el argumento por el modelo en los versos decimotercero y decimocuarto: "Cuanto la noche cierra o abre el día: /Dédalo, laberinto, enigma, Edipo?”. En palabras de Perelman, este tipo de argumentación,

(...) como el argumento de autoridad, supone que se trata de una autoridad que por su prestigio sirve de caución a la acción considerada. Es la razón por la cual aquellos que saben que son modelos deben prestar atención a lo que hacen y a lo que dicen. (1998, pp.148-149)

Se trata del uso de una figura que represente el modelo de algún valor determinado. En el caso de los versos citados, el argumento por modelo radicaría en el empleo de las figuras de Dédalo y Edipo; ambos personajes míticos icónicos de la búsqueda del hombre por su destino y la verdad. Según las estrategias hasta ahora revisadas, la referencia a estos dos personajes está relacionada con la legitimidad de quienes accederían al "cristal" de Apolo; aquellos que, justamente, emprendieran su búsqueda, así a los poetas les correspondería esta gloria.

\subsubsection{Visión de mundo}

La influencia de Arthur Schopenhauer en Borges es fundamental para comprender la propuesta de poemas como este. El poema expone, a partir del uso de metáforas y técnicas argumentativas, la tesis de que la escritura no puede capturar lo real trascendente. Aquí también es importante señalar la importancia del pensamiento platónico; según Borges, y Platón, entre el mundo sensible y el mundo inteligible, existe una distancia que el hombre no puede salvar por medio del lenguaje. Los grandes modelos del mundo de las ideas son “copiados" imperfectamente y es por medio de estas copias que conocemos y nombramos nuestra realidad. Borges; sin embargo, plantea que solo a través de un contacto con esta esfera, a través de algún nexo divino quizá, el poeta puede acceder al arquetipo y a la cuota de universalidad que detenta. 


\subsubsection{Análisis interdiscursivo}

Para el análisis comparativo de este apartado, hemos seleccionado el poema "A un poeta menor de la antología”, texto que también pertenece a El otro, el mismo (1964). El gran tema de este texto es el destino inequívoco del hombre: la muerte y el olvido. El cuestionamiento al lenguaje se trata, por tanto, en función a estos dos tópicos; sin embargo su lectura comparativa, permite evidenciar y extender el análisis de "Un poeta del siglo XIII" y comprender en mayor profundidad la poética de Borges. Una metáfora importante es la del primer verso: “¿Dónde está la memoria de los días”, la personificación de “días” es relevante pues, estos representan el tiempo. El tiempo adquiere protagonismo en el poema; a través de este, el hombre transita sin mayor gloria, pues solo es "una palabra en un índice". Aquí Borges utiliza la conceptualización de lenguaje como materia finita para establecer una analogía con la, también finita existencia del hombre. Por otro lado, señala el poeta que los dioses, como únicos poseedores de "la verdad", la inmortalidad y la gloria, escogen a qué poetas recompensar; sin embargo, ello solo se reduce a las burdas representaciones humanas: "inscripciones y exergos y monumentos y puntuales historiadores". Nótese que los elementos enumerados son tecnologías del lenguaje; Borges insiste en enfatizar la naturaleza insuficiente del lenguaje frente a la magnificencia de los dioses. Un punto crucial entre ambos poemas es el uso del símbolo del "ruiseñor"; en "A un poeta menor de la antología", se lee: "de ti solo sabemos, oscuro amigo, / que oíste al ruiseñor, una tarde". Al igual que en "Un poeta del siglo XIII", aquí el ruiseñor simboliza el arquetipo universal de la inmortalidad (recuérdese el ensayo "El ruiseñor de Keats"), el que es portador de la verdad, o el que transmite las huellas de lo real. En ambos textos, se reflexiona sobre la compleja labor del poeta, quien solo puede cultivar la esperanza de que algún día lo visite el ruiseñor, de que en algún momento pueda tentar a conocer lo que está fuera del lenguaje, la mortalidad.

\subsection{Análisis de "Una rosa y Milton"}

\section{UNA ROSA Y MILTON}

1 De las generaciones de las rosas

2 Que en el fondo del tiempo se han perdido

3 Quiero que una se salve del olvido,

4 Una sin marca o signo entre las cosas 
5 Que fueron. El destino me depara

6 Este don de nombrar por vez primera

7 Esa flor silenciosa, la postrera

8 Rosa que Milton acercó a su cara,

9 Sin verla. Oh tú bermeja o amarilla

10 O blanca rosa de un jardín borrado,

11 Deja mágicamente tu pasado

12 Inmemorial y en este verso brilla,

13 Oro, sangre o marfil o tenebrosa

14 Como en sus manos, invisible rosa.

\subsubsection{Partes del texto argumentativo}

En este poema identificamos un exordio desde el verso primero hasta el verso quinto, al cual titulamos: "La recuperación del arquetipo". En este segmento Borges explica, a través del símbolo "rosa", que el arquetipo, la universalidad de la idea, ha sido corrompida por el "signo", es decir el lenguaje. Por ello, el busca una "rosa" impoluta, es decir, la que esté libre de nominación. La narración comprende desde verso quinto "El destino me depara", hasta el decimosegundo, al cual titulamos: "La rosa que se nombra". En esta parte se narran las incidencias en torno al nombramiento de la arquetípica rosa de Milton, poeta inglés famoso por su obra Elparaiso perdido, epopeya en la cual se remite a los orígenes de mundo según la tradición cristiana. Debido al carácter de la obra de Milton, Borges le adjudica la rosa arquetípica, la del origen. El necesita de esta rosa para "nombrarla” por primera vez. Finalmente, la peroración está constituida por los versos decimotercero y decimocuarto, al este segmento lo hemos titulado "La imposibilidad de aprehender la rosa".

La tesis del autor que proponemos para este poema es la siguiente: El poeta desea restituir el arquetipo de la rosa, a través de la captura de su universalidad original en el poema.

\subsubsection{Tipos de metáfora}

La construcción metafórica predominante es la ontológica; en el verso séptimo encontramos, "Esa flor silenciosa". Lakoff y Johnson sostienen que este tipo de metáforas "permiten considerar acontecimientos, actividades, emociones, ideas, etc., como entidades o sustancias" (1980, p. 64). En ese sentido, cuando Borges vincula "flor" con "silenciosa", 
está relacionando términos en función de una definición del elemento principal, en este caso la flor. En el poema, se exige la pureza de la flor, por ello, es necesario que esté desprovista de lenguaje, de allí la necesidad de señalar su "silencio". Otra metáfora de la misma naturaleza es la del verso décimo: "O blanca rosa de un jardín borrado". Nuevamente se plantea la relación entre ambos términos, en el cual, "borrado" contribuiría a denominar "jardín”. Si entendemos el término en estricto, "borrado" refiere a la anulación o eliminación pero en relación con lo escritural. Por ello, comprendemos que “jardín” posee un carácter lingüístico. En esa línea interpretativa, la rosa que pertenece a este jardín, guardaría la misma naturaleza escritural del jardín. Quizá es por esta razón que en los versos siguientes el poeta le exija: "Deja mágicamente tu pasado".

En cuanto a las metáforas orientacionales, en los versos primero, segundo y tercero, identificamos una que construye sus vínculos desde el interior, respecto del exterior (dentrofuera):

De las generaciones de las rosas

Que en el fondo del tiempo se han perdido

Quiero que una se salve del olvido, (...)

Aquí se aprecia, la posición de las "generaciones de las rosas" en el espacio "fondo" o dentro del tiempo, en donde este último vendría a constituirse como un espacio mayor, una superficie porosa. Respecto de ese "fondo" o dentro del tiempo, se presenta "el olvido", el cual se articula desde la negación del espacio "dentro". Siguiendo esa línea interpretativa, el olvido pertenecería a una esfera fuera del tiempo. La rosa, el arquetipo, debe ser rescatada del tiempo para restituirle su universalidad.

\subsubsection{Los interlocutores}

En este poema identificamos un locutor personaje: "Quiero que una se salve del olvido". Por otro lado, se presenta un alocutario personaje representado, en este caso es la rosa a quien el poeta se dirige: "Oh tu bermeja o amarilla/ O blanca rosa de un jardín borrado". Habría que precisar que al principio del poema, el texto se presenta como un monólogo, posteriormente se suscita el diálogo con la rosa o, más precisamente, con el arquetipo de la rosa. 


\subsubsection{Técnicas argumentativas}

El argumento por contradicción e incompatibilidad es uno de los más certeros para establecer una relación de "definición" a partir de la negación o contraposición. Podemos ubicar un ejemplo en los siguientes versos:

Deja mágicamente tu pasado

Inmemorial y en este verso brilla,

Oro, sangre o marfil o tenebrosa

Como en sus manos, invisible rosa.

Tal como se aprecia se presenta una contradicción entre los dos enunciados propuestos "Deja mágicamente tu pasado inmemorial y en este verso brilla", termina dejando en evidencia que la rosa a la que se refiere es de naturaleza sensible, pues se sujeta a ser percibida, "brilla". Por otro lado, en "Oro, sangre o marfil o tenebrosa como en sus manos, invisible rosa", se indica literalmente la inmaterialidad de la rosa. Esta relación es propuesta en la medida de que el arquetipo de rosa que el poeta pretende rescatar, tendrá que ser cautiva del poema, "verso", por ello adquiriría materialidad. En cambio, el segundo enunciado se refiere al arquetipo "puro" o a la idea aún no aterrizada en el papel. De esta forma, el poeta marca las diferencias entre el arquetipo universal, incognoscible y su representación lingüística finita. En el poema la palabra "rosa" puede parecer la misma; sin embargo, se trata de dos elementos opuestos por su naturaleza.

Otro argumento fundamental en el poema es el de definición o identidad: "Esa flor silenciosa, la postrera/ Rosa que Milton acercó a su cara”. En estos versos se define a partir de los dos enunciados el concepto de "rosa". "La flor que es silenciosa y postrera, es la que Milton acercó a su cara", sería el argumento lógico literal. A partir de esta definición podemos identificar si el poeta se refiere a la rosa arquetípica que desea rescatar o a la rosa lingüística, la que habita en el poema y el olvido. Si el poeta la relaciona con el silencio, podemos comprender que la desnuda de lenguaje, por ello, se trata de una flor universal, ajena al tiempo y al mundo sensible. Siguiendo esa lógica, la flor arquetípica, la universal, es aquella a la que Milton, alguna vez, pudo acceder. 


\subsubsection{Visión de mundo}

Desde una mirada platónica, en el poema se construyen dos rosas: una es la arquetípica universal, la excede a los límites del lenguaje y sus representaciones; y otra que es una copia de la idea de la rosa universal. La primera es inaprensible, pues habita en el mundo de las ideas, la segunda se haya cautiva en el verso, bajo los límites de la escritura. El poeta cree que es posible rescatar el arquetipo ya desgastado de la rosa a lo largo de la historia del hombre, por ello busca la rosa de Milton, la rosa del origen.

\subsubsection{Análisis interdiscursivo}

Planteamos una lectura comparativa entre "Una rosa y Milton" y "El otro", poema que también integra el volumen El otro, el mismo. En "El otro" de Borges, la idea del arquetipo es primordial al igual que en "Una rosa..."; en este caso, el hombre, es el mismo a lo largo de su historia, su arquetipo también es posible. El lenguaje es la gran redada para el hombre, su historia está representada por una tecnología de la representación limitada. Algunos versos definitivos de "El otro" son los siguientes:

Da el despiadado dios que no se nombra:

A Milton las paredes de la sombra,

El destierro a Cervantes y el olvido.

Suyo es lo que perdura en la memoria

Del tiempo secular. Nuestra la escoria.

En los primeros versos se corrobora que el lenguaje corrompe el modelo ideal, por ello el poeta señala que el dios "no se nombra". Nuevamente, se utiliza la figura de Milton; en este caso, su empleo estaría inscrito en un argumento por el modelo. Su figura significa una autoridad, o, en todo caso, está asociada con la idea de su obra El paraíso perdido, en el cual se hallan los modelos universales. El origen del mundo.

\section{Conclusiones}

- El análisis literario basado en la Retórica General Textual permite acercase a la obra poética de Borges, particularmente a El otro, el mismo (1964) desde una óptica hermenéutica integral, pues considera no solo el estudio de las figuras formales presentes en los poemas, sino, además, a través de la categoría "campo retórico", 
el conocimiento del contexto escritural, el proceso de recepción de la obra, y las influencias estilísticas y filosóficas presentes en el texto.

- Para el análisis de los textos poéticos, en este caso los seleccionados de El otro el mismo (1964), se considera crucial la aplicación complementaria de los modelos de análisis retóricos de la Retórica general textual de Stefano Arduini y el de la Retórica de la argumentación Chaïm Perelman y Lucie Olbrechts-Tyteca. En primer lugar, examinar la composición de los versos ateniendo a los campos figurativos, contribuyó a identificar ciertos hallazgos estilísticos y discursivos de primer orden, ya que la aplicación de este modelo permite vincular estrechamente el plano formal con las estructuras de pensamiento del plano discusivo. En segundo lugar, entender el poema como un texto argumentativo y analizar las técnicas argumentativas presentes en él proporcionó una lectura de los poemas con mayores posibilidades interpretativas, pues se evidenciaba el constante posicionamiento del autor de sus tesis poéticas y visión de mundo.

- Finalmente, para conseguir un abordaje hermenéutico integral de El otro el mismo, se considera pertinente adicionar el análisis desde el clásico modelo retórico de George Lakoff y Mark Johnson, ya que permite desentrañar los significados que solo pueden ser hallados desde la examinación de las metáforas. Ello, contrastado con los hallazgos arrojados tras el análisis de las técnicas argumentativas, proporciona una red de sentidos mayor, lo que posibilita comprender a cabalidad la propuesta del autor respecto de la conceptualización del lenguaje como materia finita e insuficiente para la expresión de la verdad, lo real trascendente.

\section{Referencias}

Ackerman, V. (2014). El divino desorden. Buenos Aires, Argentina: Editorial Capital intelectual.

Alazraki, J. (1999). Los dos estilos del primer Borges. El Cultural. Recuperado de http:// www.elcultural.com/revista/letras/Los-dos-estilos-del-primer-Borges/14537

Arduini, S. (2000). Prolegómenos a una teoría general de las figuras. Murcia, España: Universidad de Murcia.

Borges, J. L. (1974). Obras completas. Buenos Aires, Argentina: Emecé. 
Borges, J. L. (1989). Obras completas (Vol. 2). Buenos Aires, Argentina: Emecé. De Torre, G. (1964). Para la prehistoria ultraísta de Borges. Hispania, 457-463.

García, C. (2004). Borges, traductor del Expresionismo: Wilhelm Klemm. Espéculo. Revista de estudios literarios, 9(26). Recuperado de https://pendientedemigracion.ucm.es/ info/especulo/numero26/klemm.html

Goloboff, M. (2014). Leer Borges. Buenos Aires, Argentina: Editorial Continente.

Holloway, J. (1977). “Everness”: Una Clave para el Mundo Borgiano. Revista Iberoamericana, 43(100-101), 627-636. Recuperado de http://revista-iberoamericana.pitt.edu/ojs/ index.php/Iberoamericana/article/view/3565/3739

Lakoff, G. \& Johnson, M. (1980). Metáforas de la vida cotidiana. Madrid, España: Cátedra.

Muñoz Millanes, J. (1977). Borges y la "Palabra del Universo". Revista Iberoamericana, 43(100-101), 615-625. Recuperado de http://revista-iberoamericana.pitt.edu/ojs/ index.php/Iberoamericana/article/view/3564/3738

Perelman, Ch. (1998). El Imperio retórico. Bogotá, Colombia: Grupo Editorial Norma.

Rodríguez, M. del C. (2009). Borges: el sueño imposible del ser. Buenos Aires, Argentina: Editorial Biblos.

Sarlo, B. (2007). Borges, un escritor en las orillas. Buenos Aires, Argentina: Seix Barral.

Verani, H. (1986). Las vanguardias literarias en Hispanoamérica (Manifiestos, proclamas y otros escritos). Roma, Italia: Bulzoni Edt.

Villegas Uribe, C. A. (2008). Borges y el Ultraísmo, la huella de su paso por España. Aportes para comprender el hispañol y la narrativa vital iberoamericana. Espéculo. Revista de estudios literarios, 13(38). Recuperado de http://webs.ucm.es/info/especulo/ numero38/boultra.html 